\title{
FINANCIAL STATEMENTS - BASIS FOR ASSESSING THE FINANCIAL PERFORMANCE FROM THE INVESTORS' PERSPECTIVE, BY MEANS OF PROSPECTIVELY ORIENTED INDICATORS
}

\author{
Aristiţa Rotilă, lecturer PhD, University of Bacau, Romania
}

\begin{abstract}
The items of information within the financial statements are presented with a general purpose, in order to satisfy the needs of all categories of users but, in this paper, we decided that, starting from the financial statements, we could approach the issue of assessing the financial performance only from the single perspective of the investors, also taking into account the market value of the company. The market value of a company represents the sum of the market values of the two components in the capital's structure: shareholders' equity and liabilities. It is considered that it is only in the case of shareholders' equity that the market value differs from the accounting value, but this is not the case with liabilities, so the "market value added" will be researched only by taking account of shareholders' equity.
\end{abstract}

\section{Keywords}

financial performance, book value, market price, earnings, dividend, market capitalization, shareholders' equity, share

As it is mentioned in the Romanian accounting norms, accounting must produce, publish and keep the information about the financial position, the financial performance and the cash flows, both for the internal requirements of the entities, and regarding the relationships with the present and potential investors, the financial and commercial creditors, the customers, the public institutions and other users ${ }^{1}$.

Equally interested in the proficient functioning of an entity and in the performance of that business, together with the investors and financial creditors, are the managers, but it is not our intention here to study performance from their viewpoint ${ }^{2}$ as well. At any rate, the managers' activities must be convergent with the interests of the investors; they must be receptive to the viewpoint and expectations of the investors regarding the "time, the attainment and evaluation of results", the main task of the management being to "bring stability, development and credible financial performance for the investment entrusted by the shareholders" ${ }^{3}$ because, when the shareholders buy

\footnotetext{
${ }^{1}$ Accounting Law no. 82/1991, republished in the Official Monitor no. 454 / 2008, art. 2, allign. (1).

${ }^{2}$ An analysis of financial performance from a managerial perspective would focus on the evaluation of returns in case of a company's activities, by means of investigating the profit and loss account (using absolute values and rates), and of the efficiency of using the company's resources, by means of a combined investigation of the balance sheet and of the profit and loss account (using different rates).

${ }^{3}$ Helfert A.E., Tehnici de analiză financiară, ghid pentru crearea valorii, $11^{\text {th }}$ edition, BMT Publishing House, 2006, pag. 131 and 162.
} 
shares, in fact they employ the firm to create value for them ${ }^{4}$.

In order to assess the financial performance from the perspective of the investors we must take into account a series of indicators measuring the profitability of their investment and the means of distributing the profits they have (the distribution rate or the ratio between the reinvested part and the one distributed as dividend), based on the current profits generated for them by the firm's activity, but we must also take into account a range of indicators measuring the expectations related to the future performances. The investors are obviously waiting for the gradual increase of the market value of their shares. Therefore, what is of main concern for the investors in the shares of a firm is a combination between the remuneration under the form of received dividends and the increase/ decrease of share-prices, an indicator which is also named total shareholder return.

Benefiting from the information regarding the past performance, with the purpose of determining the prospective dimension of a company's financial performance, the investors will appeal to a correlated analysis of the information deriving from the financial statements with information regarding the market price (the share list) of the shares. In that sense, together with the indicators earnings per share, dividend per share, book value of a share and return rate on shareholders' equity, resulting from the financial statements, there can be calculated a series of indicators characterizing the expectations or hopes of the investors regarding the achievement of future earnings.

Such indicators which "prospectively consider a company's financial performance" are: price/earnings ratio - PER; dividend yield - DIVY; price/ book value ratio. By means of these indicators the position occupied on the market by a certain company can also be caracterized, these indicators being also known as market indicators or indicators of the market position.

We could also include in the category of indicators which take account of the prospective financial performance of a company the earning per share if, when calculating it, we could take into account not the net earning but the comprehensive income of the accounting period ${ }^{5}$, which is oriented towards the future because it takes into consideration not only the profits and losses achieved, recognised in the profit and loss account, but also the ones which have not been achieved yet but will be confirmed in the future and which, on a regular basis, are recognised in the shareholders' equity.

For our study we examined the information presented in the financial statements of a commercial company in Romania which operates in the field of "building and repairing spatial aircrafts and crafts", which we conventionally call here S.C. ALFA S.A. The company in view has been listed on the Bucharest Stock Exchange (BVB) since 1998. At the same time, we have also acquired some information from the site of the market where the ALFA shares are traded.

The indicators afferent to the company for the period 2003-2007, representing the data necessary for the calculation, as well as the values resulting from the calculation, are presented by us in the table below.

Table no. 1: Indicators of S.C. “ALFA" SA

\footnotetext{
4 Tabără N., Horomnea E., Dicu R., Performanţa firmei în contextul reglementărilor internaţionale, part 2, in the journal Contabilitatea, Expertiza şi Auditul Afacerilor, No. 6/2008, pag. 20.

${ }^{5}$ See Jianu I., Evaluarea, prezentarea şi analiza performanţei întreprinderii: o abordare prin prisma Standardelor Internaţionale de Raportare Financiară, CECCAR Publishing House, Bucureşti, 2007, pag. 457.
} 


\begin{tabular}{|c|c|c|c|c|c|c|}
\hline Indicator $\quad$ Year & 2002 & 2003 & 2004 & 2005 & 2006 & 2007 \\
\hline $\begin{array}{l}\text { Nominal value of share } \\
(\mathrm{NV}) \text { - lei/share }\end{array}$ & 2,50 & 2,50 & 2,50 & 2,50 & 2,50 & 2,50 \\
\hline $\begin{array}{l}\text { Book value of share (BV) } \\
\text { - lei/share }\end{array}$ & 3,16 & 3,32 & 3,43 & 3,59 & 5,70 & 5,68 \\
\hline $\begin{array}{l}\text { Average value of share on } \\
\text { market }\left(\mathrm{P}^{6}\right)-\text { lei/share }\end{array}$ & 3,14 & 3,23 & 3,91 & 4,73 & 5,70 & 16,89 \\
\hline $\begin{array}{l}\text { Net earnings per share } \\
\text { (EPS) - lei/share }\end{array}$ & 0,52 & 0,55 & 0,52 & 0,58 & 1,15 & 0,87 \\
\hline $\begin{array}{l}\text { Dividend per share (DPS) } \\
\text { - lei/share }\end{array}$ & 0,35 & 0,36 & 0,35 & 0,44 & 0,87 & 0,65 \\
\hline $\begin{array}{l}\text { Distribution rate } \\
\text { (DPS/EPS) }\end{array}$ & $67 \%$ & $65 \%$ & $67 \%$ & $76 \%$ & $76 \%$ & $75 \%$ \\
\hline Price/earnings ratio (PER) & 6,04 & 5,87 & 7,52 & 8,16 & 4,96 & 19,41 \\
\hline Dividend yield (DIVY) & $11,15 \%$ & $11,15 \%$ & $8,95 \%$ & $9,30 \%$ & $15,26 \%$ & $3,85 \%$ \\
\hline $\begin{array}{l}\text { Price/ book value ratio } \\
(\mathrm{P} / \mathrm{BV})\end{array}$ & 0,99 & 0,97 & 1,14 & 1,32 & 1,00 & 2,97 \\
\hline
\end{tabular}

But before interpreting the performance indicators oriented towards the future, we can firstly observe the attitude of the company's management regarding its dividend policy. The ratio between the reinvestment and the distribution of the profit is clearly in favour of distribution under the form of dividends, the distribution rate having values between $65 \%$ and $76 \%$ in all the period surveyed. The evolution of the two indicators, the earning per share ${ }^{7}$ and the dividend per share, as well as the evolution of the absolute value of the net earning and of the dividends, indicators which influence the investors' future decisions, can be represented as follows:

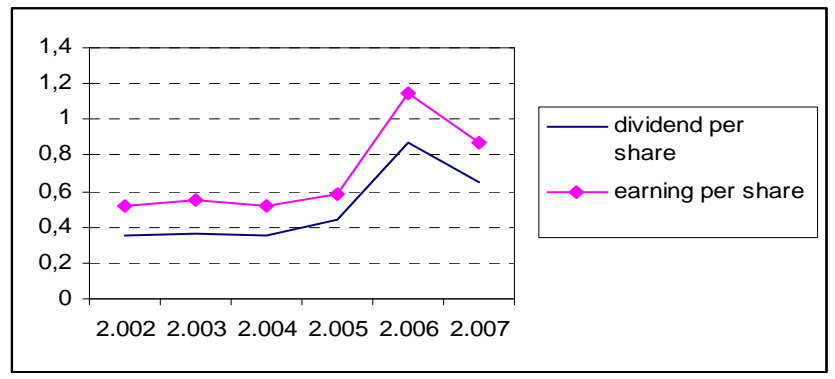

Figure no. 1. Indicators earning per share and dividend per share

\footnotetext{
${ }^{6} \mathrm{We}$ use this term since we have not taken into account a market price at a certain moment but an average price calculated for all the transactions that took place each year at a time.

${ }^{7}$ We must mention the fact that all the shares of the company are ordinary ones and there are no potential ordinary shares which would induce the issue of dilution of earnings for ordinary shares and of determining the earning per share in two ways, the basic one and the diluted one.
} 


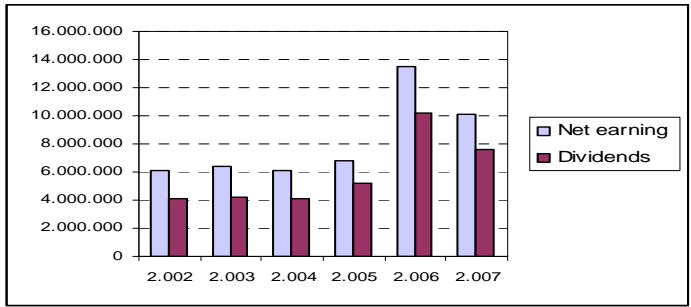

Figure no. 2. Indicators net earning and dividends

At the same time, two other values appear in the calculation of the indicators suggested for analysis, namely, the market price (in our study, the average value of a share on the market) and the book value of a share.

The difference between these two indicators (price per share - book value of share) explains the "market created value" for a share which, at the level of the company, is equal to the difference between market capitalization ${ }^{8}$ and the shareholders' equity.

According to the theory of the efficient markets, the share list "reflects, as a tendency, the future performance" of the issuing entity, and constitutes "one of the clearest signals connected to the performance of a listed company", and an increase in the share list is interpreted as "the investors' anticipation of a performance in continuous improvement and the vice versa" ${ }^{\text {. }}$. A minority investor, deprived of the possibility to take decisions at the management level of the entity in which he invested, could use as a means of influencing the decisions related to the entity only the "share list" and, if the entity offers any reasons of unease, he could take the decision of selling the shares. Similarly, the strategic investor could take a series of major decisions for the entity's life, such as the substantial alteration of the policy concerning investments, the choice of clients or suppliers, financing, payment etc., or, in other words, "he could create a greater value for the company" and will "generally be interested in paying a higher price than the share list".

A comparative evolution of the two values per share, the market price and the book value, will be presented in the following figures.

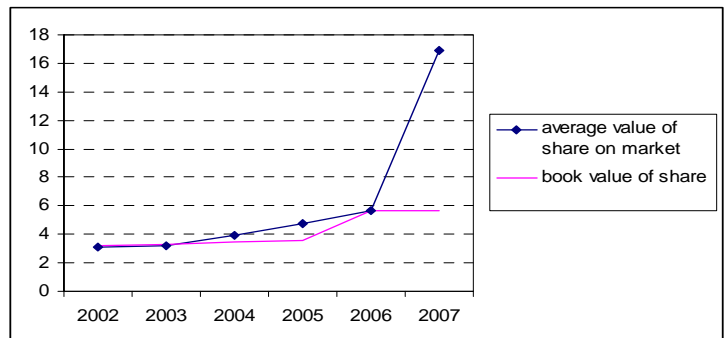

Figure no. 3. Value per ALFA share

From the diagram presented in Figure no. 3. we can observe that both the book value

\footnotetext{
${ }^{8}$ The value according to which the shareholders' equity of a firm is assessed by the market, also named "market capitalization", is determined by the product between the number of shares issued and the market price of a share.

9 Dragotă V., Ciobanu A., Obreja L., Dragotă M., Management financiar, Vol. 1: Analiză financiară şi gestiune financiară operaţională, The Economic Publishing House, Bucureşti, 2003, pag. 94-95.
} 
and the market value of a share underwent an ascending evolution between 20022007 , excepting the last year, when the book value went through a slight descent at the level of a share (5,68 lei compared with 5,70 lei, the permanent capitals dropping with $0,44 \%$ ). The two values had close amounts in 2002 and 2003, the differences between them, very small ones (0,02 lei and 0,09 lei), being favourable to the book value, which means that the value created by the market was a negative one. Between 2004 and 2005 the market value increased, exceeding the book value with 0,48 lei/ share $(13,99 \%)$ in 2004 , respectively with 1,14 lei/ share $(31,74 \%)$ in 2005 , which means that the market added value for the company. On 31.12.2006, as a result of the reassessment of the constructions (16.522.383 lei revaluation differences) and of going through a significant increase of the financial result of the financial year as compared to the previous financial year (almost its double $-197,80 \%$, from 6.800 .130 lei to 13.450 .668 lei), the book value which, previously, as we have shown, was below the market value with 1,14 lei/ share, reached the level of the one last mentioned, namely, 5,70 lei/ share. It is evident that there are many factors influencing the market price of an entity's shares, but we consider that the reporting of such a net profit in the financial statements, which meant almost a doubling of the earning per share (a growth from 0,58 lei to 1,15 lei), had positive effects concerning the market price in the period following the general assembly (12 April 2007) which endorsed the financial statements, including the distribution of the net profit for dividends in a proportion of $75,76 \%$ (10.190.878 lei). As a consequence, in 2007 , the book value $(5,68 \mathrm{lei} / \mathrm{share})$ is significantly exceeded by the market price (16,89 lei/ share - the annual average, respectively $16,25 \mathrm{lei} / \mathrm{share}$ - the average in December). The evolution of the average trading price in 2007 is presented in the following diagram.

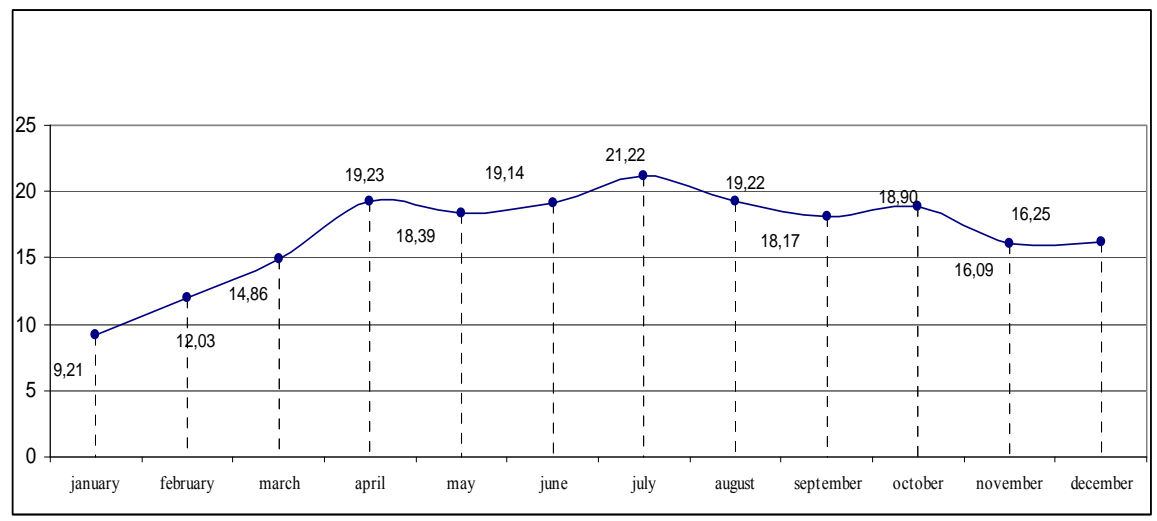

Figure no. 4. The monthly evolution of the average trading price of ALFA shares in $2007^{10}$

On the basis of these two values, the market price and the book value, we determine the value of the prospectively oriented indicator concerning performance, the price/ book value ratio.

The price/ book value ratio $(\mathbf{P} / \mathbf{B V})$ characterizes the investor's policy from the perspective of supplementary gains (lower or higher) expected for the future. The indicator establishes the ratio of the value "attributed by the investors" to the entity and its book value resulting from the balance sheet.

In the case of S.C. ALFA SA, the extent of the P/BV indicator evolved during those

${ }^{10}$ Source: Annual Report, 2007, S.C. „ALFA” SA. 
six years as shown in the following diagram:

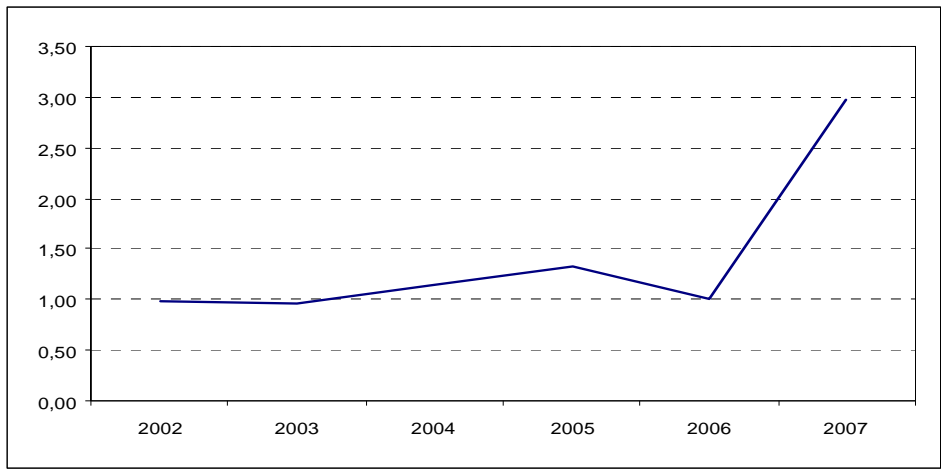

Figure no. 5. The evolution of the indicator price/ book value

It can be observed that, if between 2002-2006 the investors, in general, appreciated the value of the entity at a value which was close to the book one (with small differences in 2004 and 2005), those who purchased shares in 2007 had a much more optimistic outlook, foreseeing that they would carry out supplementary gains in the future and, as a consequence, they attributed an almost threefold value to the company, the dimension of the ratio price/ book value being of 2,97.

Regarding the indicator price/ earnings ratio (PER), also known as earnings multiplier or capitalization coefficient, it is used as a general estimator of the manner in which the market judges the financial performance of the company and its prospects ${ }^{11}$. It is one of the most frequently used analysis indicators in case of entities listed on the stock exchange, indicating how much an investor is ready to pay for a unit (one leu) from the profit per share achieved by the entity. This indicates, at the same time, the time unit (measured in years) in which an investor who purchases certain shares at the current market price can retrieve his investment on the basis of the annual net profits of that particular entity.

From the diagrams below we can observe that the investors who purchased ALFA shares paid a different price from a year to another for a leu from the profit per share, which means that even their range of expectations for the recovery of the investment is different, this commonly being between about 5 years (4,96 years in 2006) and 8 years $(8,16$ years in 2005), with the exception of the investors in 2007 who, we might say, bought the profit per share for a period of 19-20 years, under the conditions that this might remain constant.

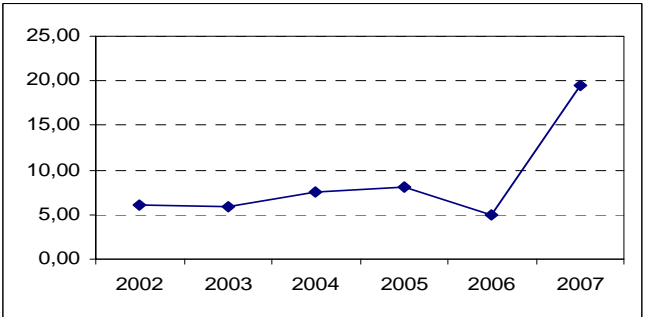

${ }^{11}$ See Tehnici de analiză financiară, ghid pentru crearea valorii, $11^{\text {th }}$ edition, BMT Publishing House, 2006, pag. 138. 
Figure no. 6. Price/earnings ratio (PER)

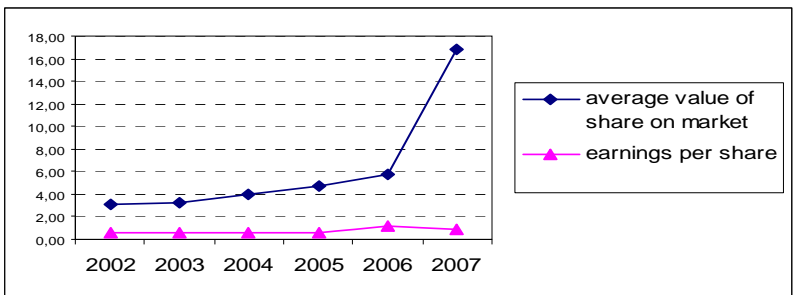

Figure no. 7. Indicators price per share and earnings per share

For an already made investment, if the earning per share increases or diminishes, and it was observed to happen from a year to another in the case of the company in our example, then the investor will have to wait for a shorter or longer period of time so as to recover his investment from the profit.

But the greater the rate of benefit growth per share is, the more attractive the share is, and the investors are more prepared to buy the earning per share for a longer period of time, which actually means a greater PER indicator, and the smaller it is then the more reduced PER is.

Another performance indicator from the investors' perspective, as we have mentioned above, is represented by the dividend yield.

The dividend yield (DIVY), also named the dividend rate or share profitability, represents the ratio between the annual dividend of a ordinary share and the market price of the share. It expresses, for the shareholders, the current profitability of a ordinary share obtained only on the basis of dividends received/ to be received, without taking into consideration the potential gains or losses of capital.

Contrary to the earning per share which conveys the theoretical enrichment of the shareholder during a year as related to a share, the dividend per share represents a cash flow.

The distributed dividend per share also partially influences the market price of a share, but the frequency of its influence is lower in the case of Romanian companies which report their dividends only annually as compared to companies in foreign countries where the dividends are reported each quarter. It is definite that certain influence with quarterly frequency can be observed in case of the dividends awaited by the shareholders, taking into account the dividend policy practised by the company by considering the quarterly net financial results. It is well-known the fact that there are requirements of quarterly reporting for the companies whose shares are admitted for trade on a regulated market, the reports being open to the public ${ }^{12}$.

In the case of the entity under study here, the dividend yield did not have a constant evolution during those 6 years, but a fluctuating one (see Figure no. 8), obviously depending on the extent of the two factors: the dividend per share and the market price of the share, whose evolution was presented above.

\footnotetext{
${ }^{12}$ See Regulation no. 1/2006 regarding the issuers and operations with securities approved by Order no. 23/2006 (art. 113) of CNVM.
} 


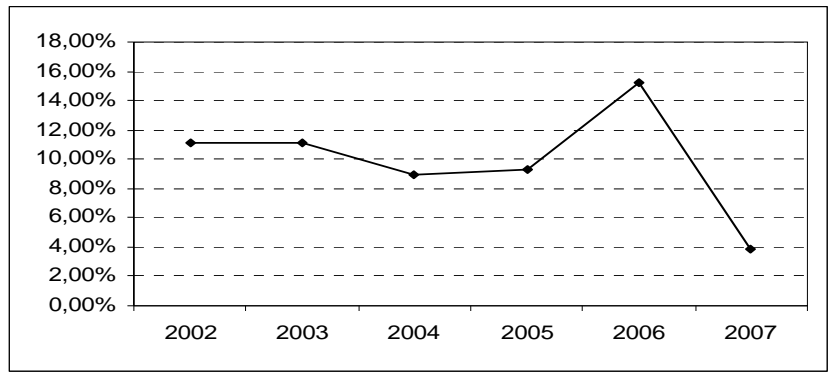

Figure no. 8. The dividend yield (DIVY)

The annual values of the indicator were of $11,15 \%$ between $2002-2003$, it undergoes a descent of $8,95 \%$ in 2004 , then it goes through ascent in the following two years, reaching the level of $15,26 \%$ in 2006. In 2007, the dividend yield declines almost four times as compared to the previous year, and this was caused particularly by the extremely strong increase of the market price (as we have shown, there was almost three times the value, from 5,70 lei/ share to 16,89 lei), and, at the same time, this was caused by a decline of the dividend per share. The evolution which was last mentioned must not necessarily be appreciated as negative as far as what matters is, as we have shown above, the total profitability for shareholder, namely the dividends per share accumulated with the increase of share prices. By means of the increase of share prices traded in 2007, the market truly created an additional value for the existing shareholders. Clearly, in order to appreciate if, on a short term, the investment in ALFA shares was the best choice for the investors in each period taken separately, it would be useful to compare this with the exchange rates on the financial market.

Depending on the evolution of these indicators from a period to another, in relation to the moment when the shares were purchased, the performance hoped for by some investors was confirmed and, as a result, they decide to maintain or increase their investment in the company, whereas for others the awaited performance was overestimated, so it was not achieved or it had no chances of achievement, and for this reason they decide to give up their investment or to diminish it. Of course, the same reasoning is available for the following period, too, for those who have just invested in such shares in the last period of the interval we have investigated.

In order to assess the market position of a certain company, these indicators regarding the expected performance are compared with the averages of the market and sector where the company operates ${ }^{13}$. In the case of S.C. ALFA SA, on the basis of the data in Table no. 2, we can observe that the values of the market indicators are superior both to the average of the activity sector ${ }^{14}$ and to the average of the market where the entity's shares are traded (Bucharest Stock Exchange). This means that the expectations concerning the company's capacity to obtain higher returns and to ensure the growth of the shareholders' wealth are higher compared to the average expectations for the companies in the sector or for the entire group of listed companies.

\footnotetext{
${ }^{13}$ We can also calculate the Market Risk, an indicator which expresses the volatility of a share price as compared to the volatility of other share prices (the ratio between the alteration of the share price of an entity and the average alteration of the price of all shares).

${ }^{14}$ At the level of the Bucharest Stock Exchange market, the entities whose shares are traded are grouped in eight sectors, the entity selected by us in this study being part of the "Products of the Manufacturing Industry" sector.
} 
Table no. 2 Indicators of the market position ${ }^{15}$

\begin{tabular}{|l|r|r|r|r|r|r|r|r|r|}
\hline \multirow{2}{*}{ Data } & \multicolumn{3}{|c|}{31.03 .2008} & \multicolumn{3}{c|}{30.06 .2008} & \multicolumn{3}{|c|}{30.09 .2008} \\
\cline { 2 - 11 } Nivelul & P/BV & PER & DIVY & P/BV & PER & DIVY & P/BV & PER & DIVY \\
\hline $\begin{array}{l}\text { Entitate: } \\
\text { S.C. ,ALFA" SA }\end{array}$ & 2,31 & 16,76 & 6,59 & 2,20 & 14,43 & 5,50 & 1,28 & 9,73 & 9,29 \\
\hline $\begin{array}{l}\text { Sector: } \\
\text { Products of the } \\
\text { manufacturing } \\
\text { industry }\end{array}$ & 1,69 & 11,87 & 2,64 & 1,23 & 10,44 & 4,40 & 1,00 & 7,09 & 5,40 \\
\hline Piaţă: $B V B$ & & & & & & & & & \\
\hline
\end{tabular}

In conclusion, even if the items of information presented in the financial statements are produced on the basis of past events and transactions, their elaboration and presentation concern the future. The users must have the possibility to perform evaluations so as to take the correct decisions. The information regarding the financial performance of the company deriving from the financial statements also lies at the basis of the indicators which characterize the expectations concerning future performance.

\section{Bibliography}

1. Dragotă V., Ciobanu A., Obreja L., Dragotă M., Management financiar, Vol. 1: Analiză financiară şi gestiune financiară operaţională, The Economic Publishing House, Bucureşti, 2003

2. Helfert A.E., Tehnici de analiză financiară, ghid pentru crearea valorii, $11^{\text {th }}$ edition, BMT Publishing House, 2006

3. Jianu I., Evaluarea, prezentarea şi analiza performanţei întreprinderii: o abordare prin prisma Standardelor Internaţionale de Raportare Financiară, CECCAR Publishing House, Bucureşti, 2007

4. Tabără N., Horomnea E., Dicu R., Performanţa firmei în contextul reglementărilor internaţionale, part 2, in the journal Contabilitatea, Expertiza şi Auditul Afacerilor, No. 6/2008 5. Accounting Law no. 82/1991, republished in the Official Monitor no. $454 / 2008$

6. Regulation no. 1/2006 on issuers and operations with securities approved by Order no. 23/2006 (art. 113) of Romanian National Securities Commission (CNVM), published in the Official Monitor no. 312 / 2006

7. www.bvb.ro

\footnotetext{
${ }^{15}$ Because we did not have access to the data regarding the sector and the market for the entire interval under study (2003 - 2007), we agreed to take into consideration the indicators established for 2008, considering at least three periods, namely the end of the first three quarters of 2008 .
} 